\title{
Optimization of the Odor Microclimate
}

M. V.Jokl

The odor microclimate is formed by gaseous airborne components perceived either as an unpleasant smell or as a pleasant smell. Smells enter the building interior partly from outdoors (exhaust fumes - flower fragrance) and partly from indoors (building materials, smoking cigarettes - cosmetics, dishes). They affect the human organism through the olfactory center which is connected to the part of brain that is responsible for controlling people's emotions and sexual feelings: smells therefore participate to a high level in mood formation. Sweet smells have a positive impact on human feelings and on human performance. Criteria for odor microclimate appraisal are presented together with ways of improving the odor microclimate (by stopping odors from spreading within a building, ventilation, air filtration, odor removal by plants, deodorization, etc.), including so-called AIR DESIGN.

Keywords: odors, microenvironment, hygiene, indor air quality, microclimate.

An optimum odor microclimate can be ensured by suitable changes in (a) the source of odors, and (b) the transfer field between the source and the exposed subject.

\section{Changes in the source of odors}

Reduction or, if possible, removal of the source of odors, is the most effective way: Construction materials that do not release an odor, and production technologies without odor sources should be preferred. Two examples of effective ways are quick setting coatings and waste baling presses.

Quick setting coatings were developed in France. They consist of a great number of low-molecular compounds and of so-called photo-initiators, which, when radiated by UV rays, rapidly (within a second) change low-molecular compounds into high-molecular compounds.

Natural materials are preferred for wood preservation, especially beeswax applied directly to cleaned wood.

Waste baling presses are awailable for home kitchens. Waste baling presses are produced by the Lescha Company (Leonard Schmid, Augsburg, Germany). A balong press can from part of a kitchen furniture suite (Fig. 1). Waste (including champagne bottles) is pressed into a polyethylene package of small volume (1/4 of the original volume) (Fig. 2). Thus, of course, any odors, or microbe release from the waste is avoided.

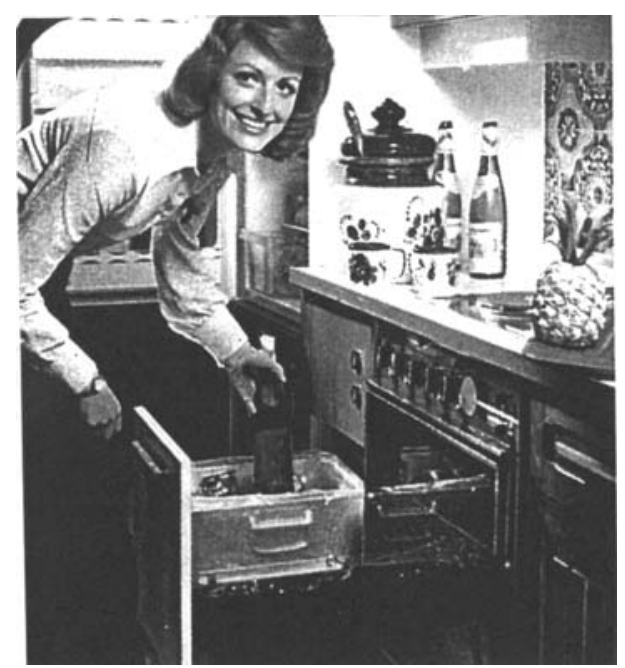

Fig. 1: The Lescha-Mollpack waste baling press integrated into kitchen furniture

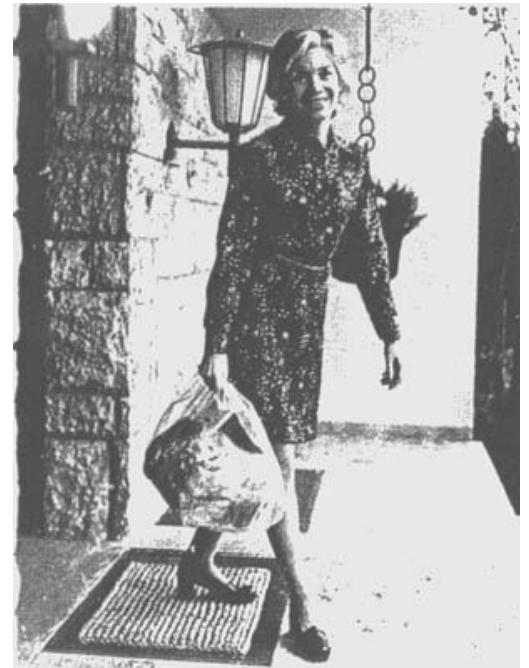

Fig. 2: The product of the waste baling press: a small polyethylene package

\section{Changes in the transfer field between source and subject}

Such changes can be made in the following ways:

a) stop the odors from spreading within the building,

b) supply an adequate quantity of outdoor air to the building interior, i.e., suitable ventilation,

c) air filtration,

d) introduction of plants,

e) chemical deodorization,

f) intensive air ionization,

g) neutralization with ionized ozone,

h) bake-out procedure.

\subsection{How to stop odors from spreading within a building}

The most effective method is to be careful about the air streams produced by infiltration and by indoor heat sources. Staircases should be divided into several hermetic parts, and the sources of odors should be confined to the upper part of the building.

The most serious problems occur in tall buildings, as a consequence of the stack effect (thermal upward pressure). According to some measurements, there is a negative pres- 




12 STORY BUILDING

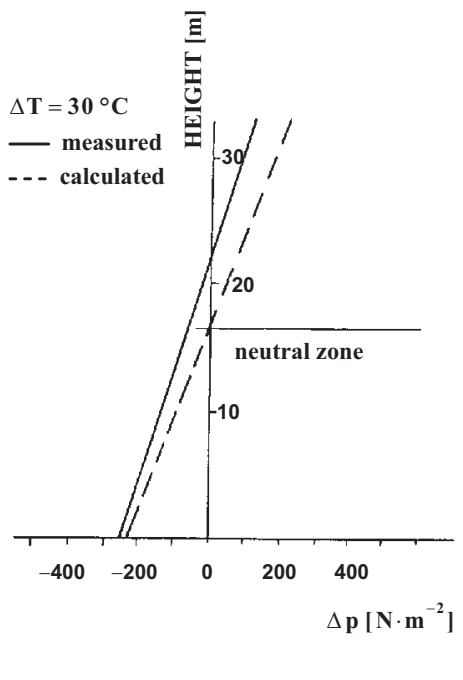

9 STORY BUILDING

Fig. 3: The air pressure distribution within a nine-story building. On the left, a schematic representation of the air pressure in a building; on the right, calculated and measured air pressure.

sure in the lower part of a 16 to 30 -storey building of 120 to $160 \mathrm{~N} \cdot \mathrm{m}^{-2}$. There is an underpressure of about $30 \mathrm{~N} \cdot \mathrm{m}^{-2}$, even at the front door of the nine-storey buildings often constructed in Europe (Fig. 3). This means, in practice, that in order to open a house-door sized about $1 \times 2 \mathrm{~m}$ it is necessary to use a force equivalent to 6,24 and $32 \mathrm{~kg}$. The effect of the thermal uplift is increased vertically through the whole building (shafts, staircases), and there is intensive spreading of odors within the building if the staircase is not divided into several hermetic parts, or if the odor sources (kitchens, laboratories, etc.) are not located in the upper part of the building. If this is impossible, at least hermetically sealed doors should be used from the staircase to the apartments or offices.

\subsection{Adequate quantity of outdoor air-ventilation}

Pettenkofer's classic value provides a basic measure for rooms where people are the main source of air pollution. For optimum concentration of $\mathrm{CO}_{2} 1000 \mathrm{ppm}=1800 \mu \mathrm{g} / \mathrm{m}^{3}=$ $=0.1$ vol. he prescribes $25 \mathrm{~m}^{3} / 1$. person. According to ASHRAE Standard 62-1989R this value can be accepted (after rounding to $7.5 \mathrm{l} / \mathrm{s} \cdot$ person $=27 \mathrm{~m}^{3} / \mathrm{h} \cdot$ person) for an unadapted person, while for adapted persons it is decreased to $2.5 \mathrm{l} / \mathrm{s} \cdot$ person $\left(9 \mathrm{~m}^{3} / \mathrm{h}\right.$ - person). By these values applying the quantity of air delivered into a room can be adjusted to the number of people: with the increasing number of people the $\mathrm{CO}_{2}$ concentration also increases, and thus the air rate



Fig. 4: The microclimate in a lecture hall controlled by a thermostat and a $\mathrm{CO}_{2}$ sensor ( 1 air rate sensor, 2 controlling flap, 3 electrical heater, 4 control unit, 5 room thermostat, $6 \mathrm{CO}_{2}$ sensor) 
must be increased, e.g., by increased fan rotations controlled by a $\mathrm{CO}_{2}$ sensor in the room (see Fig. 4). Energy also increases, savings, an important factor, are made as a result of decreased energy consumption for warming outdoor air.

The following equation should be used in the rooms where odor agents, released from building materials, are decisive for outdoor air rate:

$$
R_{\mathrm{B}}=\frac{G_{\mathrm{B}}}{3.6\left(\rho_{\mathrm{iTVOC}}-\rho_{\mathrm{eTVOC}}\right)}\left[1 / \mathrm{s} \cdot \mathrm{m}^{2}\right]
$$

where

$R_{\mathrm{B}}=$ minimum outdoor air rate related to $1 \mathrm{~m}^{2}$ of floor $\left[\mathrm{l} / \mathrm{s} \cdot \mathrm{m}^{2}\right]$,

$G_{\mathrm{B}}=$ TVOC rate produced within an interior $\left[\mu \mathrm{g} / \mathrm{h} \cdot \mathrm{m}^{2}\right.$ floor] (see Table 1$)$,

$\rho_{\text {eTVOC }}=$ TVOC concentration in outdoor air $\left[\mu \mathrm{g} / \mathrm{m}^{3}\right]$ (see Table 2$)$,

$\rho_{\mathrm{iTVOC}}=$ prescribed TVOC limit $\left[\mu \mathrm{g} / \mathrm{m}^{3}\right]$ (see Table 2 and Fig.6).
The required outdoor air rate is the sum of the two air rates (if they occur), i.e., calculated from TVOC and based on $\mathrm{CO}_{2}$.

An air change (the number of times that the air in a room is changed during one hour) is often prescribed. Thus the outdoor air rate can be obtained if the air change is multiplied by the room volume. The value calculated in this way, can differ from the outdoor air rate, which is estimated from the air rate necessary for one person, as it is evident from the following examples.

Example 1: Lecture hall crowded with students. The outdoor air rate related to one person can be lower than the prescribed value, e.g., $27 \mathrm{~m}^{3} / \mathrm{h}$.person, i.e., too low, even if high air change six has been taken into account.

Example 2: A hangar in which one person is repairing an airplane. The outdoor rate related to one person can be much higher than the prescribed value, e.g., $27 \mathrm{~m}^{3} / \mathrm{h}$.person, i.e., excessively high, even if only air change one has been taken into account.

The outdoor air rate related to one person is decisive in each case, i.e., if calculations are based on air change, the re-

Table 1: TVOC Emission rates in a building interior

\begin{tabular}{|c|c|c|c|c|}
\hline \multirow[t]{2}{*}{ Location } & \multicolumn{2}{|c|}{ TVOC $\left[\mu \mathrm{g} \cdot \mathrm{h}^{-1} \cdot \mathrm{m}^{-2}\right.$ floor $]$} & \multirow[t]{2}{*}{ Author } & \multirow[t]{2}{*}{ Note } \\
\hline & Mean & Range & & \\
\hline Existing buildings, offices & 1,550 & $100-4,890$ & EUR 14449 EN (1992) & Converted olf value \\
\hline Working hours (9-11) & 360 & $132-691$ & Ekberg (1993) & \\
\hline Night-time (5-7) & - & $90-467$ & Ekberg (1993) & \\
\hline Schools (classrooms) & 1,550 & $620-2,780$ & EUR 14449 EN (1992) & Converted olf value \\
\hline Kindergartens & 2,060 & $1,030-3,810$ & EUR 14449 EN (1992) & Converted olf value \\
\hline Assembly halls & 2,570 & $670-6,790$ & EUR 14449 EN (1992) & Converted olf value \\
\hline Dwellings & 720 & $360-1,080$ & EUR 14449 EN (1992) & \\
\hline New PVC floor tiles & 795 & $450-1,400$ & Brown and Crump (1993) & \\
\hline $\begin{array}{l}\text { Low-polluting buildings (target } \\
\text { values) }\end{array}$ & - & $260-510$ & EUR 14449 EN (1992) & Converted olf value \\
\hline $\begin{array}{l}\text { Solid flooring materials (vinyl, } \\
\text { carpet, chipboard) }\end{array}$ & \multicolumn{2}{|c|}{ Typical below 55} & Crump et al (1997) & Emission rates constant \\
\hline Wall and ceiling materials & & & Crump et al (1997) & Emission rates constant \\
\hline Plasterboard & \multicolumn{2}{|l|}{$\max 6$} & & \\
\hline 6-mm plywood & \multicolumn{2}{|l|}{$\max 10$} & & \\
\hline 15-mm plywood & \multicolumn{2}{|l|}{$\max 12$} & & \\
\hline $\begin{array}{l}\text { Bitumienised fibre board as- } \\
\text { phalt }\end{array}$ & \multicolumn{2}{|l|}{$\max 30$} & Crump et al (1997) & Emission rates constant \\
\hline PVC skirting board & \multicolumn{2}{|c|}{ Below the detection limit } & Crump et al (1997) & \\
\hline Polythene spacer & \multicolumn{2}{|c|}{4 when heated to $40^{\circ} \mathrm{C}$} & & \\
\hline Rockwool (cavity wall) & \multicolumn{2}{|c|}{ Below 15} & Crump et al (1997) & Emission rates declined slowly \\
\hline
\end{tabular}


Table 2: TVOC and $\mathrm{CO}_{2}$ concentrations in outdoor air

\begin{tabular}{|l|c|c|l|l|}
\hline Location & TVOC $\left[\mu \mathrm{g} \cdot \mathrm{m}^{-3}\right]$ & $\mathrm{CO}_{2}[\mathrm{ppm}]$ & \multicolumn{1}{|c|}{ Source } & \multicolumn{1}{|c|}{ Note } \\
\hline At sea & 0 & $300-340$ & $\begin{array}{l}\text { ICAO 1964, } \\
\text { EUR 14449 EN }\end{array}$ & Converted decipol value \\
\hline In a city, good air quality & $\begin{array}{c}14 \\
15-18\end{array}$ & 350 & $\begin{array}{l}\text { EUR 14449 EN } \\
\text { Ekberg 1993 }\end{array}$ & Converted decipol value \\
\hline In a city, bad air quality & 71 & $350-400$ & $\begin{array}{l}\text { EUR 14449 EN } \\
\text { Brown and Crump, 1993 }\end{array}$ & Converted decipol value \\
\hline
\end{tabular}

sults must be proved by calculations of air rates related to one person. Furthermore, if recirculation is used in an air handling system, the outdoor air rate must not be lower than 10 $\%$ of all air delivered into the room.

\subsection{Air filtration}

There must be a special material for odor absorption: activated carbon, charcoal or synthetic resin (e.g., amberlite). Odors can also be removed by an odor scrubber (odor washer), a biowasher, catalytic burning, biofilters, and even by plants [6].

Activated carbon has better odor-removing properties than charcoal (carbonized wood). It is produced by the impact of hot steam (800-1000 ${ }^{\circ} \mathrm{C}$ ) and zinc chloride on charcoal. This process enlarges and purifies the cells. As a result, the internal surface is enlarged up to $500-1500 \mathrm{~m}^{2} / \mathrm{g}$, i.e., in aver- age to an unbelievable value of $1000 \mathrm{~m}^{2} / \mathrm{g}$. Other kinds of coal and peat are also used and, even coconut shells (see Fig. 5).

Activated carbon absorbs very little air humidity, and does not change the chemical or psychrometric condition of the air. The odor removal efficiency depends on the contact period of the gas with the carbon. For least $80 \%$ efficiency, and an air velocity of 2.5 to $3.0 \mathrm{~m} / \mathrm{s}$, the thickness of the carbon layer should be $2.5 \mathrm{~cm}$. The efficiency depends on the carbon retention: the absorbed odor quantity $[\mathrm{g}]$ is related to $100 \mathrm{~g}$ of carbon (see Table 3).

Activated carbon is mostly applied in air cleaners. It is evident from the retentions presented in Table 7 that this device is not efficient against all odors in the same way: some odors are trapped very efficiently (e.g. human body odors), others are only slightly reduced, e.g., fish odors (odors of preparations for plant protection).

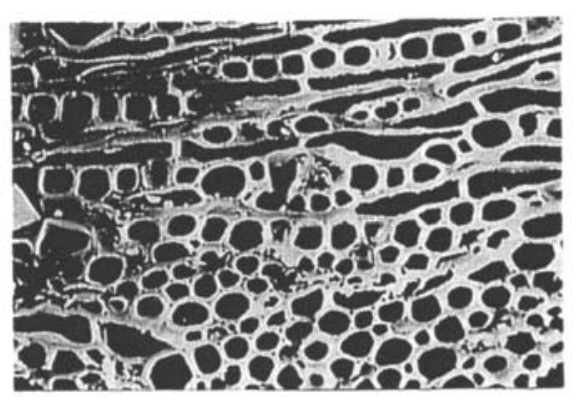

Carbonised Wood

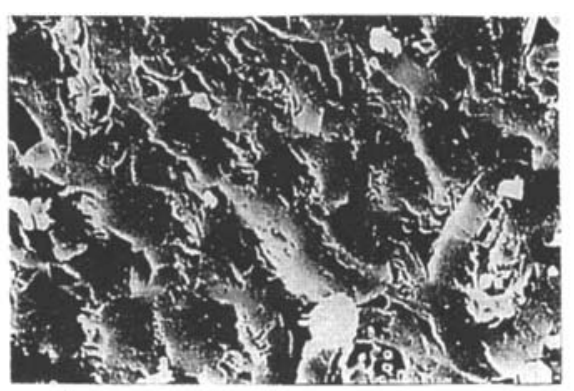

Carbonised Coconut Shell

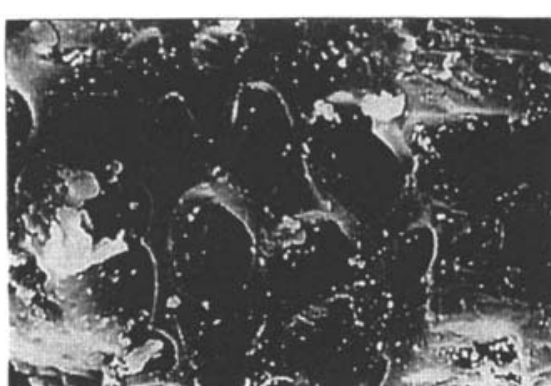

Activated Coal

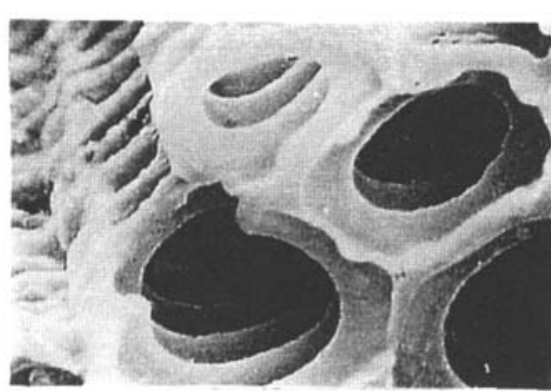

Activated Coconut Shell

Fig. 5: Microscope photos of carbonized and activated coal 
Table 3: Retention values for activated coal (charcoal)

\begin{tabular}{|l|c|}
\hline \multicolumn{1}{|c|}{ Odor agent } & $\begin{array}{c}\text { Retention }[\%] \\
{[\mathrm{g} / 100 \mathrm{~g} \text { coal }]}\end{array}$ \\
\hline Solutions & 25 to 35 \\
\hline Exhaust gases & 20 \\
\hline Body odor & 35 \\
\hline Ether & 15 \\
\hline Onion, garlic & 15 \\
\hline Antiseptics & 30 \\
\hline Tobacco smoke & 25 \\
\hline Aliphatic mercaptans $($ oil refineries, chemical industry) & 1 \\
\hline Aromatic mercaptans $($ oil refineries, chemical industry) & 15 \\
\hline Aliphatic amines (fishing indistry) & 1 \\
\hline Higher hydrocarbons $\left(>\mathrm{C}_{14}\right)$ (chemical industry) & 15 \\
\hline Aliphatic chlorohydrocarbons (chemical industry) & 15 \\
\hline Plant protection chemicals (agriculture stocks, chemical industry) & \\
\hline
\end{tabular}

\subsection{Odor removal by plants}

Indoor plants can be used as room detectors and $\mathrm{CO}_{2}$ consumers, and some are also able to clean the air from acetone, benzene, $\mathrm{CO}$, ethanol, formaldehyde, methanol, $\mathrm{SO}_{2}$, toluene and some VOCs (see Table 4). A lawn can be effective in an atrium: an area of $15 \times 15 \mathrm{~m}$ is a sufficient source of oxygen for a family with four members, and it also cleans $\mathrm{SO}_{2}$,
$\mathrm{CO}_{2}$ and hydrogen fluoride from the air. It has not been explained satisfactory what is going on with these absorbed chemicals: whether they are only stored, or perhaps used for energy consumption. It has already been proven by NASA that some of them nourish microorganisms that grow on and near the roots. Therefore flowers in a vase or plants growing in hydroponics are useless for this purpose. Potted plants growing in substrate enriched by active carbon are benefi-

Table 4: Odor removal by plants

\begin{tabular}{|c|c|c|c|}
\hline & Odor agent & Source & Affecting plants \\
\hline 1 & Acetone & Body odor & Lily \\
\hline \multirow[t]{3}{*}{2} & \multirow[t]{3}{*}{ Benzene } & \multirow[t]{3}{*}{ Office solvents } & Chrysanthemum \\
\hline & & & Gerberum \\
\hline & & & Lily \\
\hline \multirow[t]{2}{*}{3} & \multirow[t]{2}{*}{ Ethanol } & Alcoholic beverages & Lily \\
\hline & & cleaning agents & \\
\hline 4 & Hydrogen fluoride & Glass processing & Grass \\
\hline \multirow[t]{7}{*}{5} & \multirow[t]{7}{*}{ Formaldehyde } & Wood products, especially & Aloe \\
\hline & & plywoods and chipboards & Azalea \\
\hline & & parquet sealants & Philodendron \\
\hline & & cork & Gum-tree \\
\hline & & laminates & Lily \\
\hline & & glues & Poinsettias \\
\hline & & cleaning agents and & \\
\hline
\end{tabular}




\begin{tabular}{|c|c|c|c|}
\hline & Odor agent & Source & Affecting plants \\
\hline & & disinfectants & Tulip \\
\hline & & cosmetics & \\
\hline & & open fireplaces & \\
\hline & & gas cookers & \\
\hline & & tobacco smoke & \\
\hline & & textiles & \\
\hline 6 & Methanol & Cleaning agents & Lily \\
\hline 7 & Sulphur dioxide & Cars, boiler rooms & Grass \\
\hline 8 & Toluene & Cleaning agents & Arek palm, Lily \\
\hline 9 & Trichloroethylene & Cleaning agents & Lily \\
\hline \multirow[t]{6}{*}{10} & \multirow[t]{6}{*}{ VOC } & Cleaning agents & Philodendron \\
\hline & & carpets & Golden potos \\
\hline & & glues & \\
\hline & & paintings & \\
\hline & & rubbish & \\
\hline & & solvents & \\
\hline 11 & Exhaust fumes & Cars & Chesnut tree \\
\hline
\end{tabular}

cial. One well-developed plant with air streaming uniformly around it at a velocity of $0.10-0.15 \mathrm{~m} / \mathrm{s}$ should be used for $9 \mathrm{~m}^{2}$ of floor area.

\subsection{Deodorization}

Deodorization is the masking of odors: covering an unpleasant odor by another, stronger and more pleasant smell, a so-called deodorant: formaldehyde, acetaldehyde, ozone, etc. However deodorants cannot be used in high concentrations owing to their toxicity: e.g., an ozone concentration should not exceed $0.1 \mathrm{mg} / \mathrm{m}^{3}$ (0.5 ppm).

Deodorization has been known for a long time. Incense has been used for ages. It is made by cutting the shrub Boswellis carteri. From notches cut into the tree, milk juice flows, which forms yellow balls in the air, called incense (alibanum). It contains 4 to $7 \%$ of ethereal oils. If it is burnt on glowing coals, pleasant smelling smoke is produced. Nowadays incense is used as an ingredient in scented candles, and is mixed with scented woods to produce a special smelling material used during Christmas.

\subsection{Intensive air ionization}

Odors can also be removed by intensive ionization of the air, i.e., by forming negative aeroions of high concentration. Even the typical odor of a bar can be removed during the night in this way, so that the room can be used for serving breakfast the following day. Air cleaners equipped with ionizers thus have a new field of application.

\subsection{Neutralization with ionized ozone}

Ionized ozone is a very effective oxidant: the molecules of odor agents are cracked and changed into water vapors, carbon dioxide and other substances (without bad smells). The ozone concentrations must be watched carefully due to its toxicity. This method should be applied at night, when no



Fig. 6: Odor removal by ionized ozone 
people are present. Ionized ozone is supplied to recirculated air (see Fig. 6).

\subsection{Bake-out procedure}

A new way of removing VOC from a building interior is the so-called BAKE-OUT PROCEDURE: the indoor temperature is raised to $30-38{ }^{\circ} \mathrm{C}$ for two or more days, and simultaneously the ventilation is increased [4]. This is even required by the authorities in the State of California. Practical experience has not yet been reported in the literature.

\section{References}

[1] BSR/ASHRAE Standard 62-1989 R Ventilation for Acceptable Indoor Air Quality.

[2] EUR 14449 EN. Quidelines for Ventilation Requirements in Buildings. Report No. 11. Commission of EC, Luxembourg, 1992.

[3] Fanger, P. O.: Introduction of the olf and the decipol units to quantify air pollution perceived by human indoors and outdoors. Energy and Buildings Vol.12, No. 1/1988, p. 1-6.

[4] Hicks, J. et al: Building Bake-Out During Commissioning: Effects on VOC Concentration. In: Proc. of the Fifth Int. Conf. on Indoor Air Quality and Climate, Vol. 3. Toronto (Can.), 1990.

[5] IAQU. Odor evaluation as an investigative tool. Indoor Air Quality Update, 1991, p.10-13.

[6] Jokl, M.: Microenvironment: The Theory and Practice of Indoor Climate. Springfield (Illinois, U.S.A.): Thomas Publisher, 1989, p. 416.

[7] Jokl, M.: The Theory of Indoor Environment of Buildings. In Czech. Praha: Vydavatelství ČVUT, 1993, p. 261.
[8] Jokl, M. V., Leslie, G. B., Levy, L. S.: New approaches for the determination of ventilation rates: the role of sensory perception. Indoor Environment Vol. 2, No. 2/1993, p. 143-148.

[9] Jokl, M. V.: Evaluation of indoor air quality using the decibel concept. Int. J. of Environmental Health Research Vol. 7, No. 4/1997, p. 289-306.

[10] Kaiser, E. R.: Odor and its measurement. In: Air Pollution. Academic Press, 1962, p. 50-527.

[11] Mc Burney, D. H., Levine, J. M., Cavanaugh, P. H.: Psychological and social ratings of human body odor. Personality and Social Psychology Bulletin No. 3/1977, p.135-138.

[12] Oseland, N. A.: A review of odor research and the new units of perceived air pollution. Watford: BRE, 1993, p. 24.

[13] Parine, N.: The use of odor in setting ventilation rates. Indoor Environment Vol. 3, No. 3/1994, p. 87-95.

[14] Pettenkofer, M.: Über den Luftwechsel in Wohngebauden. München, 1858.

[15] The Human Body. Bratislava: GEMINI, 1992

Miloslav V. Jokl, Ph.D., Sc.D, University Professor phone: +420224354432

fax: +420233339961

e-mail: miloslav.jokl@fsv.cvut.cz

Czech Technical University in Prague

Faculty of Civil Engineering

Thákurova 7

16629 Prague 6, Czech Republic 